\title{
Difference in Raindrop Size Distribution and the Z-R Relationship with Elevation
}

\author{
By Miyuki Fujiwara, Ichitaro Ichimura and Toshiko Yanase \\ Meteorological Research Institute \\ (Manuscript received 10 April 1971)
}

\begin{abstract}
Comparisons were made between the $Z-R$ relationships which were obtained from the data taken at three elevations $3.4,2.1$ and $1.3 \mathrm{~km}$ above the sea level along the eastern slope of $\mathrm{Mt}$. Fuji. The precipitation observed was considered as generated from clouds of the warm-rain type. Raindrops were sampled by using filter paper during two shower rains. The $Z-R$ relationships at each elevation were as follows:

$$
\begin{array}{ll}
Z=48 R^{1.11} & (3.4 \mathrm{~km}) \\
Z=88 R^{1.28} & (2.1 \mathrm{~km}) \\
Z=240 R^{1.48} & (1.3 \mathrm{~km})
\end{array}
$$

The significance of the difference between the parameters was consistent with the tendency in the showers in Hawaii Island which was interpreted by Fujiwara (1967) through accretion and evaporation.
\end{abstract}

\section{Introduction}

On the problem how much raindrops develop during their fall, several investigations have been presented so far (Rigby et al. 1954, Hardy 1963). This is a research intended to make another step forward along this line by observation.

An organized field work program was carried out at the eastern slope of Mt. Fuji during the period from 19th to 28th June, 1967 (Uchida et al. 1969) by a cloud physics research group of the M.R.I. Raindrop samplings were obtained by means of dyed filter paper simultaneously at three elevations $7.8 \mathrm{GO}(3,400 \mathrm{~m}$ above sea level), $2.8 \mathrm{GO}(2,100 \mathrm{~m}$, ditto) and Tarobo $(1,300 \mathrm{~m}$, ditto). The topography is shown in Fig. 1. Out of the raindrop data obtained during the observation period, only those taken on 20th June were analyzed in the present study, in order to clarify what differences occur, and why, in raindrop distribution and the $Z-R$ relationship at different elevations.

\section{Synoptic aspects of the rain system}

Although weak rain started at about 1300 JST, our raindrop data are based on drops which fell rather heavily from 1630 to 1820 and from 1900 to 2030 on 20th June.

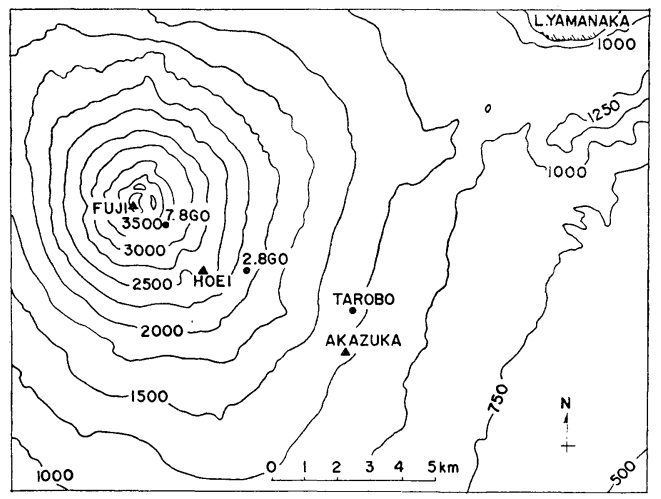

Fig. 1. Topography around the network. The values on the contours are given in meters above sea level. The three stations $7.8 \mathrm{GO}, 2.8 \mathrm{GO}$ and Tarobo are at $1,300,2,100$ and $3,400 \mathrm{~m}$ above sea level, respectively.

The radar observation $\log$ and weather charts show that the rainfall was associated with a southward mesoscale depression on the stationary front which lay off the south coast of, and in parallel to, the main island of Japan. Along the south coast of Japan were scattered airmass-type echoes and cumulus clouds, some having anvil tops. Such cloud status and weather situation indicate that the airmass was conditionally unstable 


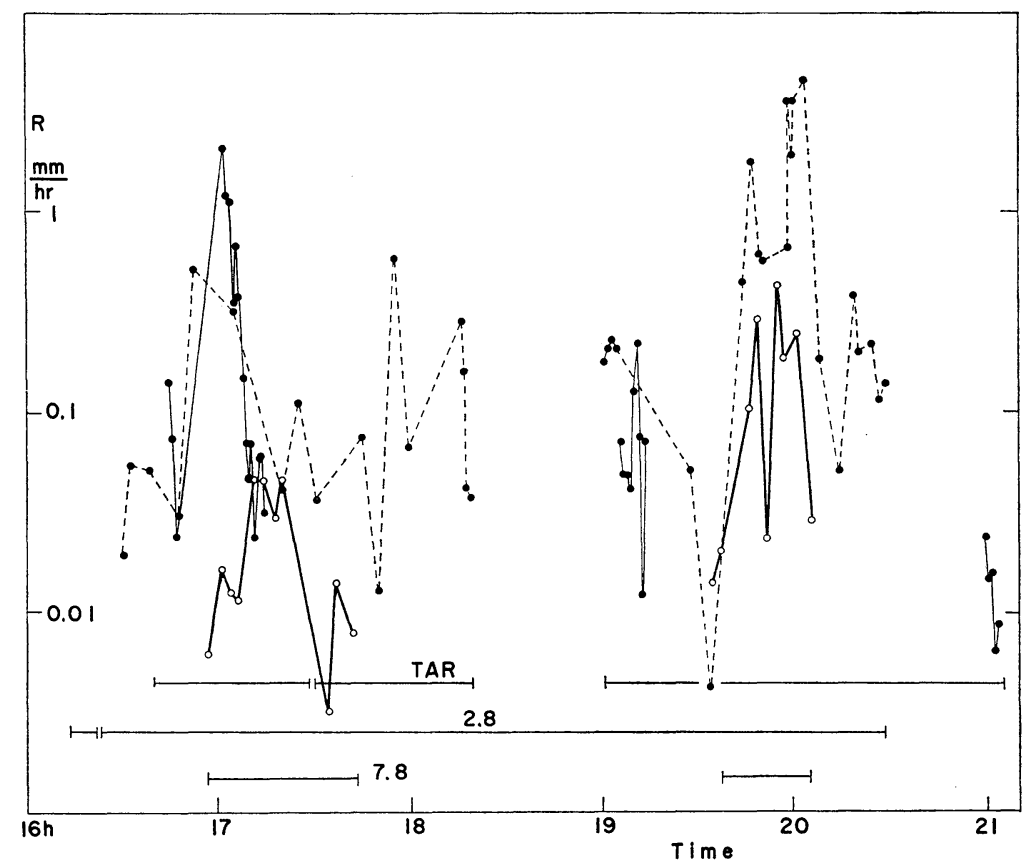

Fig. 2. Rainfall rates calculated from raindrop data taken at the three elevations on 20 June, 1967. Thin solid lines: Tarobo $(1.3 \mathrm{~km})$; dashed lines: $2.8 \mathrm{GO}(2.1 \mathrm{~km})$; heavy solid lines: $7.8 \mathrm{GO}(3.4 \mathrm{~km})$. Horizontal bars at the bottom show the durations of rainfall.

the whole day.

The rainfall rates at the three stations were calculated from the raindrop data and shown in Fig. 2. Thin solid, dashed, and heavy solid lines represent the stations Tarobo, $2.8 \mathrm{GO}$, and 7.8 GO, respectively. It is shown that, though the fluctuation is considerable owing to the small sampling size, the rain intensity differs by about one decimal order on the average for each elevation of about $1 \mathrm{~km}$. It is also shown that the peaks of the rainfall rate occurred in succession as if the system moved from the east/lower station (Tarobo) to the west/upper station (7.8 GO) in the earlier rain system, besides from the west /upper station (7.8 GO) to the east/lower station (2.8 GO) in the later system. This change is in accordance with that of the wind direction which occurred in the afternoon.

The durations of rainfall are shown by five horizontal bars at the bottom of the figure. Of the three stations that at $2.8 \mathrm{GO}$ saw the longest rainfall.

The general airflows around the network were approximately parallel to the W-E plane. Two hodographs of the winds, which were observed at
Hamamatsu about $120 \mathrm{~km}$ southwest of Mt. Fuji, are shown in Fig. 3. Thin and heavy lines represent observations made at 0830 and 2030 JST, respectively. Heights are given beside each link point in $\mathrm{km}$. Although a few exceptional levels observed in the morning, 0.65-1.05 and 2.6-3.45 km, have a considerable N-S component

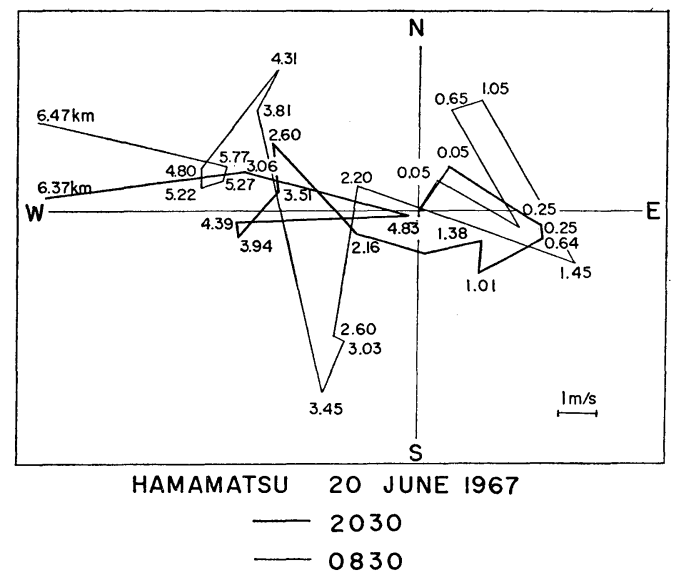

Fig. 3. Upper wind hodographs from the radiosounding at Hamamatsu. Numbers given are heights in $\mathrm{km}$. 
which is considered to have been caused by the sea breeze, most of the points are distributed approximately in a ESE-WNW line. The three sampling stations are also nearly parallel to this line. Therefore, a kinematical analysis of cloud and precipitation which moving horizontally with the winds can be made in this two-dimensional vertical plane with an approximation. Generally speaking, the low level winds were easterly, but the upper level winds westerly, the change in direction occurring between $2.8 \mathrm{GO}$ and Tarobo.

\section{Kinematical analysis of the cloud system}

For a simplified analysis, the vertical pattern of the horizontal wind at 1700 JST was determined by applying an interpolation of two the data shown in Fig. 3. By using this pattern a few samples of streaks and trajectories of precipitation and bubble were drawn as shown in Fig. 4. (Here "bubble" means a rising air parcel which contains growing drops.)

On the other hand, a series of photographs of clouds were taken from Tarobo for every 15 minutes. It was shown that the cloud base was about $1,300 \mathrm{~m}$ above sea level, but varying from

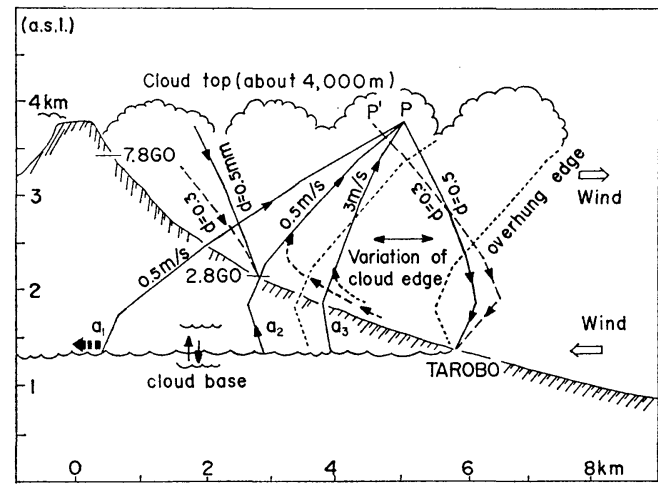

Fig. 4. Pattern of bubble $\left(a_{1}-P, a_{2}-P, a_{3}-P\right)$ and precipitation trajectories from the cloud top which were drawn according to the wind data in Fig. 3. The cloud base was assumed to be at the level of Tarobo on the average. The set-up point $a_{1}$ is assumed to move with the general wind at the level, whereas $a_{2}$ and $\mathrm{a}_{3}$ are imaginary fixed set-up points of ascending parcels with 0.5 and $3 \mathrm{~m} / \mathrm{s}$ respectively. Actually the general wind on the ridge is modified by the hill, and the realistic patterns will be some as shown by the dashed arrows.
$1,200 \mathrm{~m}$ to $1,800 \mathrm{~m}$ above sea level. Although the cloud was mostly obscure during the rainfall, a remarkable overhanging form of cloud was sometimes observed by eye right overhead extending to the east. Such overhanging edge of the cloud seen from Tarobo can be interpreted kinematically by the trajectory of a bubble, as shown in Fig. 4 (dotted curves). The drawing of the trajectories of rising air parcels was made under the assumption that the parcel yields entirely to the horizontal wind.

A few examples of the pattern of the streaks of bubbles and ensuing precipitation shown in the figure were determined in the vertical E-W plane, and these are given by the curves from $a_{1}, a_{2}$ and $a_{3}$ to Tarobo through cloud top $P$. Curves $a_{2}-P$ and $a_{3}-P$ represent the pattern of stationary streaks of the rising air parceles under two assumed updraft velocities $0.5 \mathrm{~m} / \mathrm{s}$ and $3 \mathrm{~m} / \mathrm{s}$ respectively. Those velocities are in the range of the updraft evaluated from the'ground wind speed and the gliding slope, and also from the photopraphs of the abjacent cumulus tops. The stationary state means that the set-up points $a_{2}$ and $a_{3}$ of the ascending parcels are fixed to the ground. On the other hand $a_{1}$ is the set-up point moving with the general wind at the level. Actually the pattern would be modified by the topographical effect as shown schematically by dashed arrows. Since the pattern of the cloud edge is considered to be paralled with the trajectory of a slow parcel, $a_{2}-p$, it would be as shown by the dotted curves.

In the decaying stage of cloud system, the setup point will leave the mountain foot and move towards higher levels. If so, the edge pattern of overhanging cloud becomes closer to the slope parallel to $a_{1}-P$, namely, the overhang extends farther. This is also consistient with the visual evidence obtained at Tarobo. The station $2.8 \mathrm{GO}$ was clearly seen from Tarobo under dark overhanging cloud during the decaying stage.

The raindrop trajectories relating to the data at Tarobo were drawn for the two fixed raindrop sizes 0.3 and $0.5 \mathrm{~mm}$, as shown by $\mathrm{P}$ - and $\mathrm{P}^{\prime}$ Tarobo, where the terminal velocities were assumed to be constant for simplicity. It is found from the analysis that for any drop size the height is much the same from which drops fall into the cloudclear layer between $1.3 \mathrm{~km}$ to $2.5 \mathrm{~km}$ under the vertical wind distribution. 


\section{Comparison of the raindrop size distributions and the $\boldsymbol{Z}-\boldsymbol{R}$ relationships at different elevations}

For comparison of the raindrop-size distributions between three different elevations the average distribution curves $N_{D}$ were calculated for the two rain systems and for the three stations, and are shown in Fig. 5. (The left-hand side is the

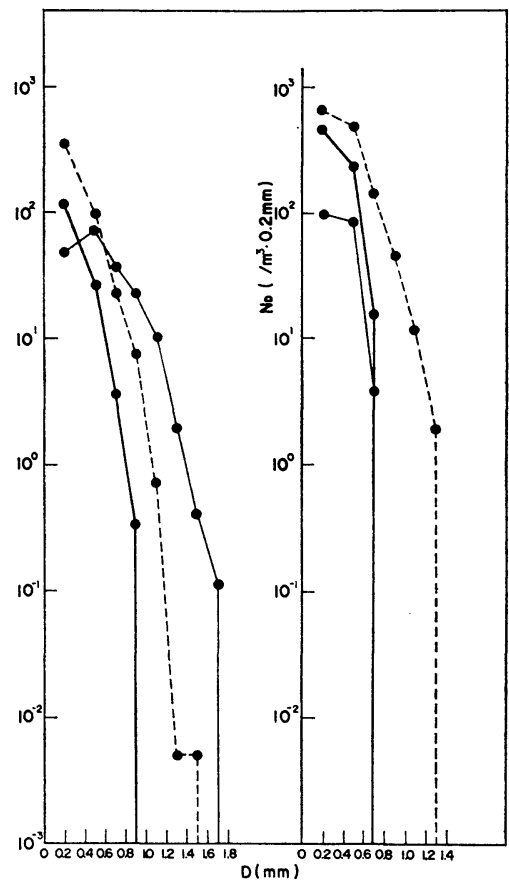

Fig. 5. Average $N_{D}$ curves of raindrops for the three stations, the left one is for the first rain system and the right one for the second rain system. (Key is as same as Fig. 2)

first rain system and the right-hand side, the second one.) First of all it is noticed that all the spectra are very narrow and have high peak concentrations (also as shown in Table 1). Since the concentration and the spectrum width have increased from the values at $7.8 \mathrm{GO}$ (heavy line) to those at $2.8 \mathrm{GO}$ (dash line) in both rain systems, it can be concluded that most raindrops were generated and grew within the layer between 3.4 and $2.1 \mathrm{~km}$ above the ground. The peak concentration of the spectrum increased by about a few times.

In the first rain system, the spectrum width continued its growth, being associated with a little dip in the concentration of small sizes during the fall of drops from 2.1 to $1.3 \mathrm{~km}$ level. But the change of the spectrum at $3.4 \mathrm{~km}$ to that at 2.1 $\mathrm{km}$ was quite similar in both rain systems. However, in the sceond rain system, both concentration and spectrum width were reduced considerably during the last fall from $2.8 \mathrm{GO}$ to Tarobo.

In Fig. 6, the plots of the radar reflectivity to the rainfall rates calculated from the raindrop data are shown for the three elevations (a), (b) and (c) corresponding to the stations Tarobo, 2.8 GO and 7.8 GO respectively. Each regression line, drawn by the least square method for $\log R$ with independent variable $\log Z$, determines the parameters $B$ and $\beta$ as defined by $Z=B R^{\beta}$. Those are given in Table 1 with their stochastic variance and the mean value of $\log R$.

\section{Rain growth in the layer between 7.8 GO and $2.8 \mathrm{GO}$}

Strictly speaking, because of the horizontal distance between the stations as shown in Fig. 1, it is not always proper to compare with each other the individual groups of raindrops observed at the two elevations as described in Sec. 3. However, it can be assumed that the average raindrop concentrations at each station shown in Fig. 5 will reveal an average modification that occurred during the fall. As pointed out previously (in the first paragraph of Sec. 4), the rainfall developed in the layer between $7.8 \mathrm{GO}$ and $2.8 \mathrm{GO}$, while it decayed generally between 2.8 GO and Tarobo. This must be due to the fact that the rain was showery. The spectrum width in the first rain system increased as the height decreases from $7.8 \mathrm{GO}$ to $2.8 \mathrm{GO}$ as well as the peak concentration, resulting in an increase in the rainfall rate from 0.07 to $0.7 \mathrm{~mm} / \mathrm{hr}$, nearly a tenfold increase. By comparison of the concentrations, it is known that the majority of raindrops were generated within the layer between these two levels. This tendency is more marked in the second rain system. Two groups of trajectories of raindrops for fixed diameters 0.3 and $0.5 \mathrm{~mm}$ are shown in Fig. 4 with downward arrow lines, dashed and solid, respectively. As shown in the figure, raindrops sampled at 2.8 GO may represent the growth attained during the $1-\mathrm{km}$ fall from $7.8 \mathrm{GO}$ to $2.8 \mathrm{GO}$. The largest drops taken at $7.8 \mathrm{GO}$ and $2.8 \mathrm{GO}$ in the first rain system, which are considered to have grown under the optimum conditions, were 0.9 $\mathrm{mm} 1.4 \mathrm{~mm}$ in diameter, respectively. The peak 


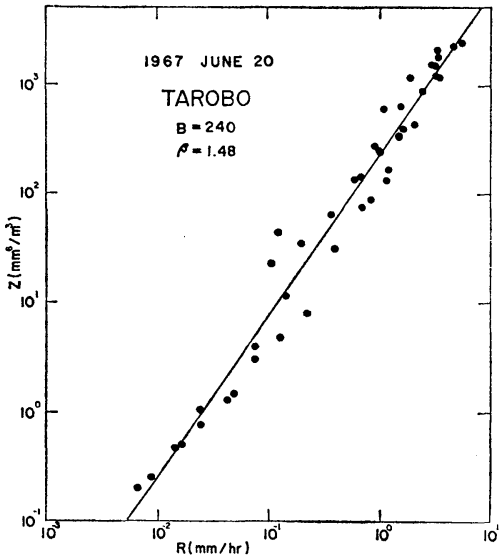

(a)

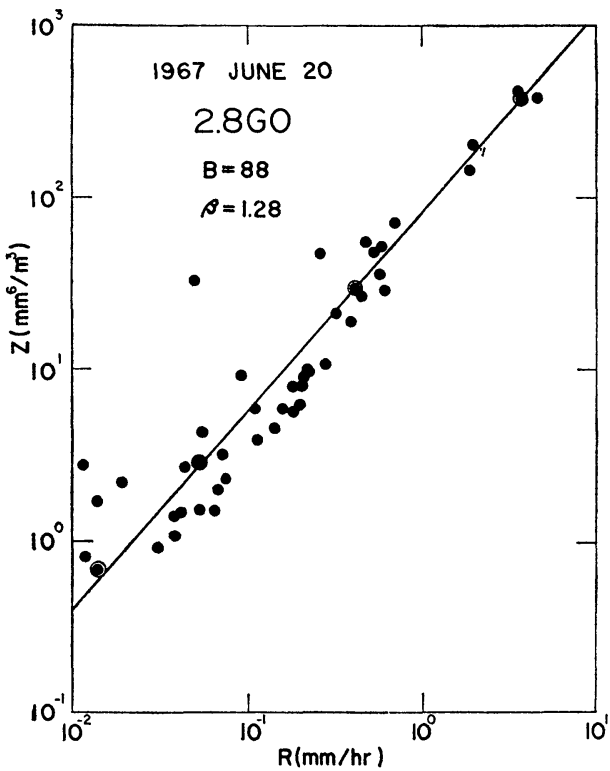

(b)

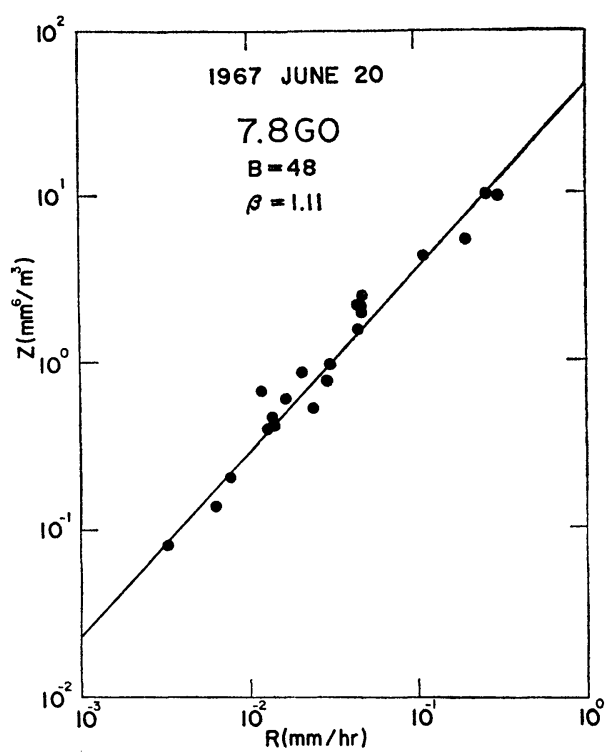

(c)

Fig. 6. The plots of the $Z-R$ relationship as calculated from the raindrop data. (a), (b) and (c) are for the sations Tarobo, $2.8 \mathrm{GO}$ and $7.8 \mathrm{GO}$, respectively. Each regression line was drawn by the least square method for $\log R$ with independent variable $\log Z$.

Table 1. Difference in the parameters of raindrop size distribution and the $Z-R$ relationship between the three elevations. The values of $S_{\alpha}$ and $S_{\beta}$ are the stochastic standard errors in the mean value of $\log R$ and in the value $\beta$, respectively, which are estimated from the $\log Z-\log R$ scatter diagram.

\begin{tabular}{|c|c|c|c|c|c|c|c|c|}
\hline \multirow[b]{3}{*}{ Stations } & \multicolumn{4}{|c|}{ Average size distribution } & \multicolumn{4}{|c|}{$Z-R$ relationship $Z=B R^{\beta}$} \\
\hline & \multicolumn{2}{|c|}{$\begin{array}{c}\text { Peak concentration } \\
\left(\text { No. } \mathrm{cm}^{-4}\right)\end{array}$} & \multicolumn{2}{|c|}{$\begin{array}{l}\text { Maximum drop } \\
\text { diameter }(\mathrm{mm})\end{array}$} & $\left(\begin{array}{c}B \\
\left(\begin{array}{c}\mathrm{mm}^{6} \\
\mathrm{~m}^{-3}\end{array}\right)\end{array}\right.$ & $\beta$ & $\left.\begin{array}{c}S \alpha \\
\left(\mathrm{mm}^{6}\right. \\
\mathrm{m}^{-3}\end{array}\right)$ & $S_{\beta}$ \\
\hline & 1st rain & 2 nd rain & 1st rain & 2 nd rain & & & & \\
\hline Tarobo $(1.3 \mathrm{~km})$ & 0.0045 & 0.0055 & 1. 7 & 0.7 & 240 & 1. 48 & 0.027 & 0.041 \\
\hline $2.8 \mathrm{GO}(2.1 \mathrm{~km})$ & 0.018 & 0.035 & 1.5 & 1. 3 & 88 & 1. 28 & 0.051 & 0.085 \\
\hline $7.8 \mathrm{GO}(3.4 \mathrm{~km})$ & 0.0058 & 0.0026 & 0.9 & 0.7 & 48 & 1. 11 & 0.033 & 0.073 \\
\hline
\end{tabular}


value of rain water content observed at $7.8 \mathrm{GO}$ and $2.8 \mathrm{GO}$ were about 0.06 and $0.2 \mathrm{gr} / \mathrm{m}$ respectively.

Also simultaneous measurement of cloud water content was done by other scientists on the project. The peak value (1900 JST) of the cloud water content at $2.8 \mathrm{GO}$ was estimated as 0.09 $\mathrm{gr} / \mathrm{m}$, although some uncertainty is still remaining. Those two kinds of water content seem to contribute to the growth of raindrops. However, the measured cloud water content does not seem to be large enough to explain the observed drop growth, as shown in the next section.

\section{Interpretation of the raindrop growth}

Although the updraft would not be uniform within the ascending bubbles and rainstreaks, the cloud structure as given in Fig. 4 suggests the possibility of applying the classical theory of warm rain proposed by Bowen (1950) to the cases in this study as a first grade apporoximation. It is assumed that the optimum conditions meet the growth of the largest drops, which were $0.9 \mathrm{~mm}$ at $7.8 \mathrm{GO}$ and $1.4 \mathrm{~mm}$ at $2.8 \mathrm{GO}$ in diameter. Raindrops growth by cloud accretion can be given by eq. (1), from $D_{0}$ to $D$ in diameter during their fall from $H_{0}$ to $H$, which is height measured from a fixed point.

$$
\frac{1}{2 \sigma}\left(H-H_{0}\right)=\frac{1}{L} \int_{D_{0}}^{0} \frac{1}{E}\left(\frac{w}{V}-1\right) d D
$$

where $\sigma, L, E, w$ and $V$ are respectively the density of water, liquid water content, collision efficiency, updraft velocity, and the terminal velocity of the drop with diameter $D$.

Each drop trajectory has a peak at the level where $w=V(D)$ in relation to $L$. As mentioned in the previous section most of the drops sampled at $2.8 \mathrm{GO}$ have the trajectory peak lower than $7.8 \mathrm{GO}$ level $(3.4 \mathrm{~km})$. About $90 \%$ of the rainfall amount at $2.8 \mathrm{GO}$ was accounted for by those drops.

Assuming that $\sigma$ and $E$ are unity calculations of eq. (1) were made for several updrafts from 1.35 to $3.8 \mathrm{~m} / \mathrm{s}$, in order to obtain the fall distances of raindrops from their trajectory peaks which would yield a diameter of $0.9 \mathrm{~mm}$ at 7.8 GO. The results are given in Table 2. The terminal velocity was modified for the effect of air density $\rho$ by eq. (2).

$$
V=V_{0} \sqrt{\rho / \rho_{0}}
$$

Since the cloud top was $600-800 \mathrm{~m}$ higher than $7.8 \mathrm{GO}$ level, the cases whose values are given in the lines of the table higher than those with double underlines are eligible. Combining this with the measured cloud water content $L(\max )$ $=0.09 \mathrm{gr} / \mathrm{m}^{3}$, the final estimations of $U_{0}$ and $D_{0}$ are given as $3.0 \mathrm{~m} / \mathrm{s}$ and $0.63 \mathrm{~mm}$ respectively. The maximum updraft $3 \mathrm{~m} / \mathrm{s}$ at the cloud top is acceptable. But the mean updraft in the layer where the drop falls will be considerably smaller than that, sometimes even changing into a downdraft. However, the maximum updraft velocity $3.0 \mathrm{~m} / \mathrm{s}$ at the cloud top is required only for the growth of the largest drop suspended at the highest point. The growth after this point should reasonably be calculated with an adequate mean updraft velocity. As expected from eq. (1). $\Delta H\left(=H-H_{0}\right)$ becomes almost independent of $w$ as the terminal velocity $V(D)$ further exceeds $w$. The estimated mean updraft associated with the fall is calculated to be about $1.5 \mathrm{~m} / \mathrm{s}$ for the diameter to grow from $0.63 \mathrm{~mm}$ to $0.90 \mathrm{~mm}$ within an error of $-10 \%$.

Table 2. Raindrop growth by cloud accretion under constant updraft conditions. The fall depth $(\Delta H)$ of the raindrops from the peak of their trajectory to $7.8 \mathrm{GO}$ which would yield a drop diameter of $0.9 \mathrm{~mm}$ at $7.8 \mathrm{GO}$ is given in relation with the uniform updraft velocity $U_{0}$ and the available liquid water content. The diameter at the trajectory peak $D_{0}$ is

\begin{tabular}{|c|c|c|c|c|c|c|}
\hline \multicolumn{2}{|c|}{ At cloud top } & \multicolumn{5}{|c|}{$\Delta H(\mathrm{~m})$, depth of drop travelling } \\
\hline$U_{0}$ & $D_{0}$ & $\begin{array}{l}\text { with } \\
0.06\end{array}$ & $\begin{array}{l}\text { liquid } \\
0.09\end{array}$ & $\begin{array}{c}\text { vater cc } \\
0.12\end{array}$ & $\begin{array}{r}\text { nt., } L= \\
\text { 0. } 24\end{array}$ & $\begin{array}{c}\left(\mathrm{gr} / \mathrm{m}^{3}\right) \\
0.1\end{array}$ \\
\hline $\mathrm{m} / \mathrm{s}$ & $\mathrm{mm}$ & & $U$ & $U_{0}$ & & $U=0$ \\
\hline 3. 80 & 0.5 & 100 & 67 & 50 & 25 & 200 \\
\hline 3. 30 & 0.7 & 385 & 257 & 193 & 96 & 400 \\
\hline 2. 87 & 0.6 & $1, \overline{200}$ & 800 & 600 & 300 & 600 \\
\hline 2. 40 & 0.5 & 3,400 & $2, \overline{270}$ & $1, \overline{700}$ & 850 & 800 \\
\hline 1. 76 & 0.4 & 6,350 & 4,230 & 3,175 & $1, \overline{587}$ & 1,000 \\
\hline 1. 35 & 0.3 & - & - & - & - & 1,200 \\
\hline
\end{tabular}
determined by $U_{0}$.

It seems, however, that the droplet's growth from its initial size to $0.63 \mathrm{~mm}$ during its ascent is rather hard to be accounted for by the accretion process. Estimations gave values about 0.3 $\mathrm{mm}$ under comparable conditions. However, in the earlier stage, it may be possible that raindrops 

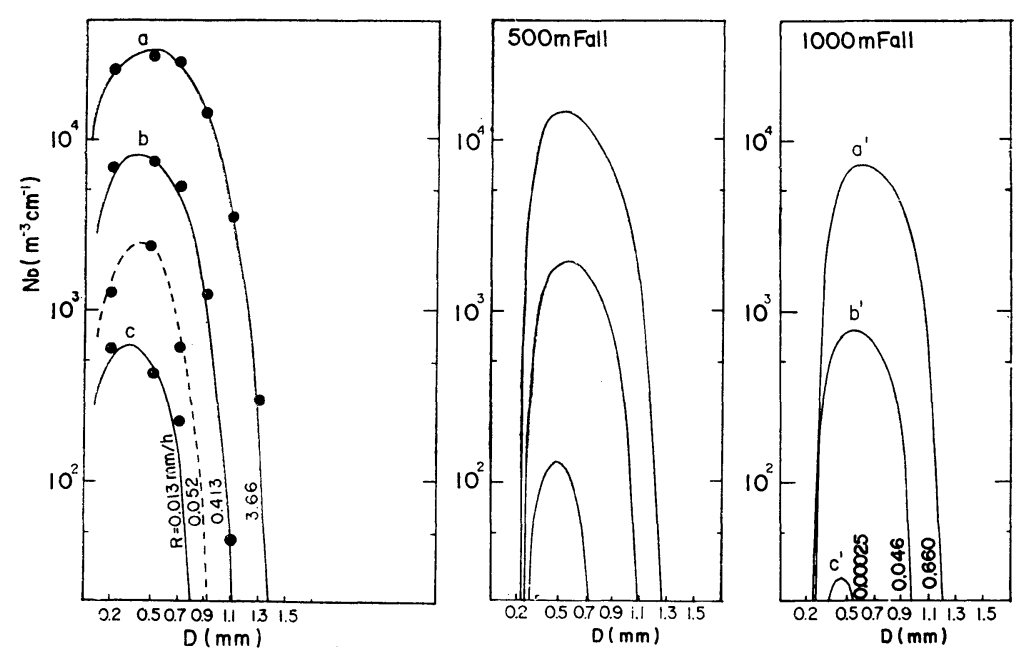

Fig. 7. Decay of the narrow $N_{D}$ curve by evaporation. The figure on the left shows the family of $N_{D}$ curve taken at $2.8 \mathrm{GO}$, $2,100 \mathrm{~m}$ above sea level. The calculated families after evaporation through $500 \mathrm{~m}$ fall and $1,000 \mathrm{~m}$ fall are shown in the middle, and on the right, respectively. The curves $\mathrm{a}^{\prime}, \mathrm{b}^{\prime}$ and $\mathrm{c}^{\prime}$ correspond to those $\mathrm{a}, \mathrm{b}$ and $\mathrm{c}$ respectively. The value beside each curve shows the rinfall intensity in $\mathrm{mm} / \mathrm{hr}$.

are in extreme spatial concentration in favorable condition for mutual collision. It is therefore concluded from this that the largest raindrop size, $0.63 \mathrm{~mm}$ in diameter by estimation, must have been attained by some additional growth probably due to stochastic collision between raindrops.

\section{Raindrop decay from 2.8 GO to Tarobo}

It was mentioned above that the raindrops observed at Tarobo had traveled one $\mathrm{km}$ of cloudfree space under the overhanging cloud, where the air remained unsaturated owing to the airflows from the east. A brief calculation of evaporation effects was made on the basis of this assumption. As a basis of calculation, a few representative $N_{D}$ curves at $2.8 \mathrm{GO}$ were selected from among the sampling data. Those are 4 points taken on the $Z-R$ regression line, as encircled in Fig. 6 (b); the corresponding $N_{D}$ curves are shown in Fig. 7 (left). One can notice from this figure that, though the curves are smoothed subjectively, the $\log N_{D}-D$ curves thus obtained are rather the symmetrically monomodal type than the skewed exponential type.

The equation for the calculation of the effects is

$$
\frac{\partial N_{D}}{\partial H}=-\frac{\partial\left[N_{D} \cdot(d D / d H)\right]}{\partial D}
$$

where

$$
\frac{d D}{d H}=f\left(D, \rho, R_{c}, \nu, T, \Delta\right)
$$

where the right-hand term is a complex function of drop diameter $D$, vapor density $\rho$ in the surroundings of the drop, Reynold number $R_{e}$, fall depth $H$ of drop relative to the air, viscosity of the air $\nu$, air temperature $T$, and diffusion coefficient of vapor $\Delta$. In the calculation of this righthand term, a convenient table by Takahashi (1957) is available. It is assumed for convenience of calculation that the temperature is $10^{\circ} \mathrm{C}$ and the humidity $85 \%$ (from radiosounding data) throughout the layer. The first equation is rewritten as

$$
\frac{\partial N_{D}}{\partial H}=\frac{-4.60}{\pi}\left(P \cdot N_{D}\right) \cdot \frac{\partial \log \left(N_{D} \cdot P\right)}{\partial D}
$$

where

$$
P=\frac{\pi}{2} \frac{d D}{d H}
$$

Then approximate calculations are made easier by using semi-logarithmic paper and the results are shown in Fig. 7.

The middle and right of the figure are the resultant $N_{D}$ curves after a fall through 500 and 
$1,000 \mathrm{~m}$, respectively. The effect of evaporation is remarkable in the range of small sizes, as shown by Best (1950). Since the rainfalls observed were weak and the mean diameter of the drops is small, the peak concentration of the curve was reduced to about one by third after fall of 500 $\mathrm{m}$, and to about one decimal order less after a fall of $1,000 \mathrm{~m}$.

The average $N_{D}$ curves given in Fig. 5 shown a reduction to about a sixth in the peak concentration. Considering the horizontal distance between $2.8 \mathrm{GO}$ and Tarobo, a large part of the magnitude of the reduction, one decimal order, may be capable of interpretation of the reduction to a sixth in the actual mean $N_{D}$ curve.

\section{Remarks on $\boldsymbol{Z}$ - $\boldsymbol{R}$ relationship}

Inspite of the considerable decay in raindrop concentration due to evaporation, the difference between the $Z-R$ regression lines does not seem remarkable as seen in Fig. $6, i$. e. the $B$ value is reduced by about $50 \%$ in association with the reduction to about a sixth in raindrop concentration. A brief examination was made of the evaporation effect on the $Z-R$ relationships as shown in Fig. 8, where a, b, c, $a^{\prime}, b^{\prime}, c^{\prime}$ are

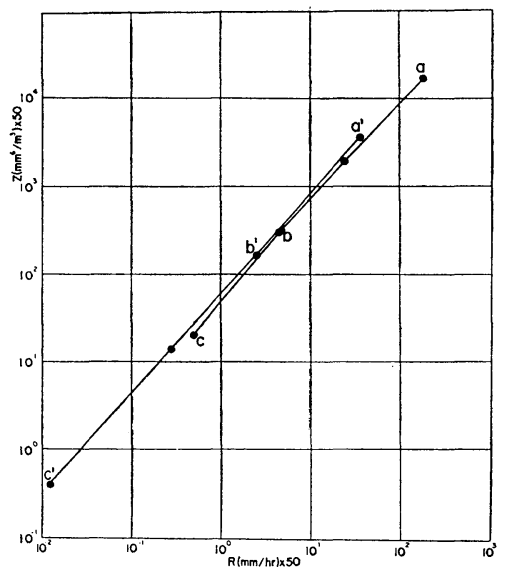

Fig. 8. Evaporation effect on raindrop $Z-R$ relationship. The curve which is indicated by a prime on the corresponding letter is that after evaporation through $1,000 \mathrm{~m}$ fall. The symbols a, $b, c ; a^{\prime}, b^{\prime}, c^{\prime}$ are the same as in Fig. 7.

the same as in Fig. 7. The $Z-R$ curves calculated are from the $N_{D}$ curves at $2.8 \mathrm{GO}$ (given at left in Fig. 7). It is shown that the two curves corresponding to $2.8 \mathrm{GO}$ and to that calculated for Tarobo (given at right in Fig. 7) seem to coincide with each other in their location within computational errors, and both curves can be expressed by one set of parameters. In other words, the evaporation in the present case, which reduces the rainfall intensity as much as by one decimal order, does not change the $Z-R$ relationship appreciably. This seems rather curious because the effect of evaporation, as is well known, increases factor $B$ while it decreases the value of index $\beta$, if the original spectrum is the Marshall-Palmer type (Atlas et al. 1957 and Imai 1960). However, it should be emphasized here that the original size distribution was the narrow monomodal type, which is directly opposite to the Marshall-Palmer type.

Consequently, the main cause of the changes in $Z-R$ relationship, which were actually measured and shown in Table 1, will be accretion of cloud droplets. The process appreciably increases the values of $B$ as well as $\beta$ (Fujiwara 1967). For a time the raindrop path from $2.1 \mathrm{~km}$ to Tarobo was cloud free, but the data involve the whole rain systems, in the earlier period of which the path was covered with cloud and consequently a considerable increase of spectrum width resulted in between 2.8 GO and Tarobo as shown at left in Fig. 5.

\section{Concluding summary}

The raindrop size distributions during orographic warm rain observed at the three elevations 3.4 $\mathrm{km}$ (near the cloud top), $2.1 \mathrm{~km}$ (about $0.8 \mathrm{~km}$ above the cloud base) and $1.3 \mathrm{~km}$ (near the cloud base but sometimes outside of the cloud system) were compared with each other. It was found that the average raindrop concentration at the middle part of the cloud was several times larger than that near the cloud top. This means that the main generation or growth source of raindrops ( $>0.2 \mathrm{~mm}$ in dia.) was in between the two stations $7.8 \mathrm{GO}$ and $2.8 \mathrm{GO}$. The optimum situation for raindrop growth is attained not only by cloud accretion but also by a stochastic process. In the case when the cloud retreated up slope, the raindrops at the cloud edge decayed by evaporzation.

Although the factor $B$ and the index $\beta$ defined by $Z=B R^{\beta}$ were not appreciably changed by evaporation alone, the resultant values $B$ and $\beta$ actually increased with the fall depth, probably because of collision effect, the $B$ value doubling 
itself and the $\beta$ value gaining $20 \%$ increase in the course of $1,000 \mathrm{~m}$.

\section{Acknowledgements}

The present study was carried out as part of the MRI Research Project of Precipitation Physics, headed by Dr. S. Ohta. The observations were therefore made in cooperation with the other members of this project, and also valuable discussions were held with them, The data reduction and drawings are due to Mrs. T. Koyama. The authors express their hearty thanks to all of these members and collaborators.

\section{References}

Atlas, D. and A.C. Chmela, 1957: Physical-synoptic variations of raindrop size parameters, Proc. 6th Weath. Radar Conf. Amer. Met. Soc. p. 21.

Best, A.C., 1952: Evaporation of raindrops. Quart. J. Roy. Meteor. Soc. 78, 200-225.
Fujiwara, M., 1967: Raindrop-size in warm rain as measured in Hawaii. Tellus XIX. 392-402.

and T. Yanase, 1970: On some characteristics of raindrop size distribution in warm-type rain. Pap. Geophys. XXII, 61-68.

Hardy, K.R., 1963: The development of raindrop-size distributions and implications related to the physics of precipitation. J. Atmos. Sci. 20, 299-312.

Imai, I., 1960: Raindrop size distributions and $Z-R$ relationships. Proc. 8th Weath. Radar Conf. Amer. Met. Soc., p. 211.

Rigby, E.C., J.S. Marshall and W. Hitschfeld, 1954: The development of the size distribution of raindrops during their fall. J. Meteor. 11, 363-372.

Takahashi, Y., 1957: Tables and Diagrams in Cloud Physics (in Japanese). Kishoogaku-koza (Meteorology) Chijinshokan, Tokyo, 19, 104-108.

Uchida, E. and S. Ohta, 1969: A simulation approach to the formation of precipitation particles using the Monte Carlo Method. J. Meteor. Soc. Japan. 47, 279-291.

\title{
雨滴の分布とその Z-R 関係の高度差について
}

\author{
藤 原 美 幸・市村市太郎・柳 瀬 利子 \\ 気象研究所
}

䁔い雲からの地形性しゅら雨の雨滴分布の高度变化を観測した例を報告する．観測点は富士山東斜面の太郎坊（高 度 $1.3 \mathrm{~km}), 2.8$ 合 $(2.1 \mathrm{~km}), 7.8$ 合 $(3.4 \mathrm{~km})$ の 3 点である. 降雨は気団型の弱いしゅう雨で雲頂は約 $4 \mathrm{~km}$ $\left(2{ }^{\circ} \mathrm{C}\right)$ であった，上層は乾燥していて下層は条件不安定で周囲にも同様な積雲が多かった，気流と雲は日中は東南東 方より這い上がり夕刻には山頂より東南東方向に下降し，降雨のピークも同様の日変化をしていた.

雨滴の分布は弱いしゅう雨の典型的な形すなわち比較的数の多いから幅のせまいスペクトルであった．雨滴の主な 生成層は 2.8 合一7.8 合間であって雲頂附近の 7.8 合 $(3.4 \mathrm{~km})$ から雲底附近の 2.8 合 $(2.1 \mathrm{~km})$ に達するまで に雨滴スペクトルのピークは 3 倍〜数倍に增加し，スペクトルの幅も増加している (Fig. 5 をみよ). しかし 2.8 合 から太郎坊までの落下ではあとのしゅう雨 (Fig. 5 右側) では減少している.

雲の上部は常に上空の西風の影響をらけて東方に懸崖状になっており雨滴の落下中の水平運動を考慮すると太郎坊 で観測された雨滴は一時雲から出て蒸発の影響をらけたことが計算によって説明される.

雨滴分布の高度变化を結論的にいえば高度と共に平均直径が小さくなり，その变化特性は降雨強度の增加が粒の数 の増加によって行なわれる典型的な弱い「䍔い雨」型となっている，Z-R 试で示すと

$$
\begin{array}{ll}
Z=48 R^{1.11} & (3.4 \mathrm{~km}) \\
Z=88 R^{1.28} & (2.1 \mathrm{~km}) \\
Z=240 R^{1.48} & (1.3 \mathrm{~km})
\end{array}
$$

である。この「䁔い雨」の雨滴の成長を古典的な Bowen 型の雲粒附着による成長のみで説明を試みると雲頂におけ る雨滴の大きさ（最大粒は直径 $0.9 \mathrm{~mm}$ ）を説明するのは困難であり, 直径にして成長の約半分位は雨滴同士のスト カスチック過程で行なわれていると仮定しないと説明困難である。しかしそれ以後は雲粒捕捉による成長が卓越する ことが暗示される. 